JOURNAL OF ENVIRONMENTAL ENGINEERING AND LANDSCAPE MANAGEMENT

http:/www.vtu.lt/english/editions

2005, Vol XIII, No 1, 31-36

\title{
ULTRAVIOLET RADIATION AND GROUND-LEVEL OZONE VARIATION IN LITHUANIA
}

\author{
Renata Chadyšiene் $\dot{1}^{1}$, Raselè Girgždienè2 $\dot{e}^{2}$ Aloyzas Girgždys ${ }^{3}$ \\ 1, ${ }^{3}$ Laboratory of Nuclear Hydrophysics, Vilnius Gediminas Technical University, \\ Sauletekio al. 11, LT-10223 Vilnius-40, Lithuania, \\ E-mail: algi@fm.vtu.lt \\ ${ }^{2}$ Institute of Physics, Savanoriu pr. 231, LT-02300 Vilnius, Lithuania, \\ E-mail: raseleg@ktl.mii.lt
}

Received 30 Nov 2004; accepted 11 Dec 2004

\begin{abstract}
Preliminary analysis of the data of ultraviolet (UV) radiation and ground-level ozone concentration measurements from Rugšteliškès Monitoring Station over the years 2002-2003 is presented. Observations showed that an average UV radiation value in January and July of 2002 differed about 10 times. Maximum intensity of UVA radiation was observed in July (about 2,4 W/m ${ }^{2}$ ), and minimal one - in December $\left(0,1 \mathrm{~W} / \mathrm{m}^{2}\right)$, the highest UVB radiation intensity was in May $\left(0,09 \mathrm{~W} / \mathrm{m}^{2}\right)$, while a minimal UVB radiation value as well as that of UVA was registered in December $\left(0,07 \mathrm{~W} / \mathrm{m}^{2}\right)$. Relationship between the highest ozone concentration and UVB radiation values during the summer of the investigation period was found to be linear.
\end{abstract}

Keywords: ultraviolet radiation, radiation intensity, ozone concentration, correlation coefficient.

\section{Introduction}

There are many different types of energy that come from the Sun. All of the types of energy are part of the electromagnetic spectrum. Electromagnetic rays of wavelengths between 2 and $400 \mathrm{~nm}$ (photon energy between 3 and $620 \mathrm{eV}$ ) are known as ultraviolet rays. Ultraviolet (UV) radiation that reaches the Earth's surface is of wavelengths between 290 and $400 \mathrm{~nm}$. Visible light is between 400 and $700 \mathrm{~nm}$ (Fig 1). UV radiation is responsible for adverse health effects. The radiation (200 and $300 \mathrm{~nm})$ is absorbed by atmospheric ozone $\left(\mathrm{O}_{3}\right)$. However, the highest amount of ozone can be found at altitudes between 19 and $30 \mathrm{~km}$ above the Earth's surface. Ozone is a combination of three oxygen atoms. It is gas produced naturally in the stratosphere. UV radiation is classified into three types or bands - UVA, UVB, and UVC. The stratospheric ozone layer absorbs some, but not all, of these types of UV radiation: UVA is not absorbed, UVB is most absorbed, but some part of it reaches the Earth's surface, and UVC is completely absorbed by the ozone layer and oxygen. UVA and UVB that reach the Earth's surface contribute to serious human health damages. UVA (320-400 nm) plays an essential role in formation of vitamin $\mathrm{D}$ by the skin, but can also evoke harmful sunburn on the human skin and cataracts in our eyes. UVB (290-320 nm) causes damage at the molecular level to the fundamental building block of life-deoxyribonucleic acid (DNA). UVB radiation harmful to living organisms is a small part of the spectrum, from 290 to 320 nanometer wavelengths, and represents about $1 \%$ of the total radiation reaching the Earth's surface (Table 1) [1].

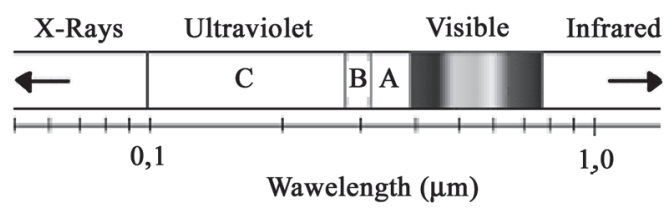

Fig 1. Spectrum of solar radiation

Table 1. Distribution of solar radiation energy

\begin{tabular}{|c|c|c|}
\hline Spectral region & Wavelength & $\%$ of total energy \\
\hline Infrared & $>700 \mathrm{~nm}$ & 49,4 \\
\hline Visible & $400-700 \mathrm{~nm}$ & 42,3 \\
\hline UVA & $400-320 \mathrm{~nm}$ & 6,3 \\
\hline UVB & $320-290 \mathrm{~nm}$ & 1,5 \\
\hline UVC & $<290 \mathrm{~nm}$ & 0,5 \\
\hline
\end{tabular}




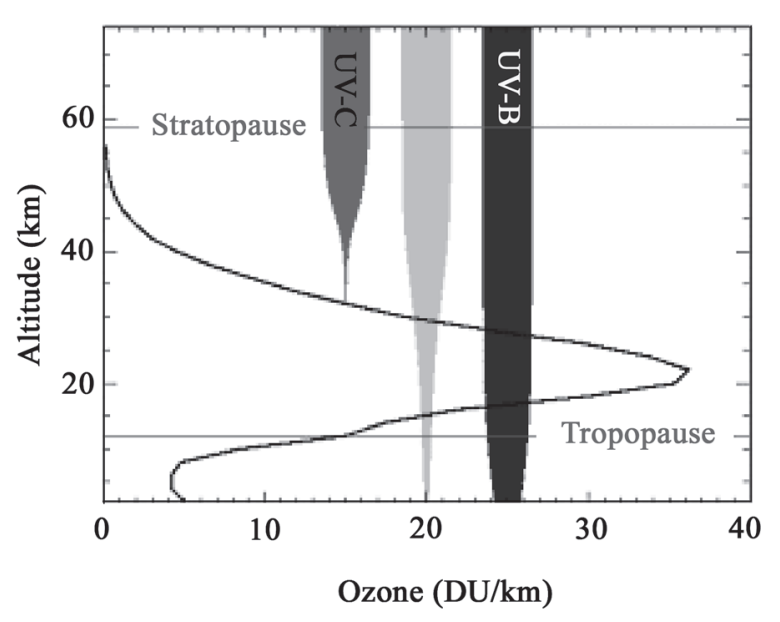

Fig 2. Vertical distribution of UV radiation and atmospheric ozone

The curve in Fig 2 [2] shows a typical vertical profile of ozone at the middle latitudes of the northern hemisphere. As mentioned above, UVC is absorbed completely in the stratosphere. $94 \%$ of UVA and $6 \%$ of UVB radiation reach the Earth's surface. Fig 2 shows that about $99 \%$ of the total UV solar radiation (all UVC and the most part of UVB range) is absorbed by atmospheric ozone [2]. It is natural origin function, protecting us from harmful influence of UV rays.

In Lithuania $49 \%$ of the total annual solar energy reaches the surface during three months: May, June and July, and only $6 \%$ during wintertime [3].

Relationship between UV radiation measured at the surface, the total ozone, aerosol properties, clouds and surface albedo are discussed in literature [4].

The amount of energy received from the Sun at the top of the atmosphere per time unit and per unit area is known as Solar constant. Its value is approximately $1370 \mathrm{~W} / \mathrm{m}^{2}$. The amount of UV radiation reaching the Earth's surface varies widely. The level of UV radiation that reaches the Earth's surface can vary depending on a variety of factors. Each of the following factors can increase UV radiation over exposure and its harmful health effects [5]. Besides the above-mentioned stratospheric ozone, such factors as time of the day and year, geographical location, weather conditions and surface reflection are very significant. The Sun is at the highest point in the sky at noon. At that time the Sun's rays have the least distance to travel through the atmosphere, and the UVB radiation level is the highest. In the early morning and late afternoon the Sun's rays pass through the atmosphere at an angle, and their intensity is greatly reduced. A cloud cover plays a highly influential role for the level of both UVA and UVB radiation reaching the ground. Each water droplet in a cloud scatters some incoming UV radiation back into space, so a thick cover of clouds protects organisms and materials from UV rays. However, a thin or scattered cloud cover can be deceiving to people who are sunbathing, and the result can be an unexpected and severe sunburn.
Decrease of the ozone layer allows penetration of more UV radiation through the atmosphere, and exposure at the Earth's surface increases. Exposure to shorter wavelengths increases by a larger percentage than exposure to longer wavelengths. At middle latitudes a decrease of one percent in the ozone layer may result in an increase of one $(310 \mathrm{~nm})$ to three $(305 \mathrm{~nm})$ percent of potentially harmful UVB at the surface during midsummer when UVB is the highest.

Ozone depletion is greater at higher latitudes, (toward the North and South Poles) and negligible at lower latitudes (between $30^{\circ} \mathrm{N}$ and $30^{\circ} \mathrm{S}$ ).

Cities at lower latitudes generally receive more sunlight because they are nearer the equator, so UV radiation levels are higher even in the absence of ozone depletion. If ozone were to decrease at lower latitudes, southern cities would experience a greater absolute increase in UVB than cities in the north for the same amount of ozone depletion.

The purpose of the work is to perform a preliminary analysis of UV radiation variations in Lithuania and to find relationship between $U V$ radiation and ozone concentration.

\section{Site description and methods}

Measurements of solar radiation and ozone concentration were carried out at Rugšteliškès Monitoring Station. The Station $\left(55^{\circ} 26^{\prime} \mathrm{N}\right.$ and $26^{\circ} 04^{\prime} \mathrm{E}$, about $170 \mathrm{~m}$ above the sea level) is situated in the eastern part of Lithuania and surrounded mainly with natural pine and spruce forests. The nearest local source of pollution is Utena town, about $25 \mathrm{~km}$ in the western direction.

Ozone concentration was measured using a commercial UV absorption ozone analyser ML9811. The lowest detection limit of this instrument was $1 \mathrm{ppb}$. The ozone measurement cycle was several seconds. The obtained data were averaged over a 1-hour period.

Solar detectors are based on the top of a meteorological tower, at $26 \mathrm{~m}$ height above the Earth's surface.

UVB radiation $(280-315 \mathrm{~nm})$ was measured using a pyranometer SKU 430. The sensor sensitivity is $150 \mathrm{mV} / \mathrm{W} / \mathrm{m}^{2}$. The sensor characteristics are shown in Fig 3.

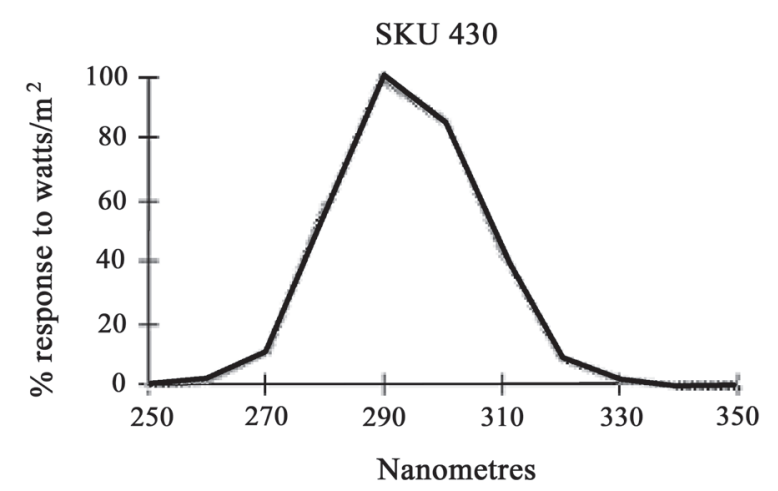

Fig 3. Characteristics of UV sensor SKU 430 


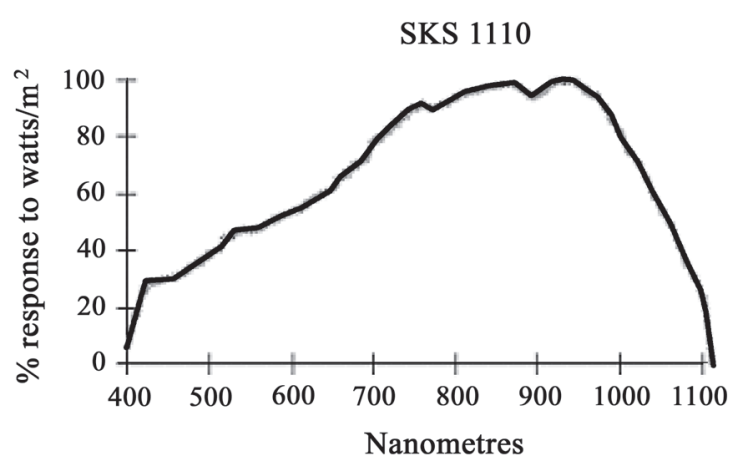

Fig 4. Characteristics of UV sensor SKS 1110

A pyranometer SKS 1110 was used to measure the total solar radiation, within $0-5000 \mathrm{~W} / \mathrm{m}^{2}$ working range and spectral response 500-1000 $\mathrm{nm}$. The sensor sensitivity is $1 \mathrm{mV} / 100 \mathrm{~W} / \mathrm{m}^{2}$ (Fig 4).

\section{Measurement results}

The data of global and UV radiation, ozone concentration obtained at Rugšteliskès Monitoring Station during 2002-2003 are analysed.

The data analysis (Fig 5) shows that an average UV radiation value in January and July of 2002 differed about 10 times. An average value of January was $110 \mathrm{~mW} / \mathrm{m}^{2}$ with the minimum $\left(37 \mathrm{~mW} / \mathrm{m}^{2}\right)$ on 6 January and maximum on 31 January $\left(273 \mathrm{~mW} / \mathrm{m}^{2}\right)$.

The July values varied from maximum on 3 July $\left(2819 \mathrm{~mW} / \mathrm{m}^{2}\right)$ to minimum on $20 \mathrm{July}\left(860 \mathrm{~mW} / \mathrm{m}^{2}\right)$. An average value of July was about $2136 \mathrm{~mW} / \mathrm{m}^{2}$, and about 19 times it was higher than an average value of UV radiation in January.

Comparison of the course of UV and global radiation was performed. Fig 6 shows the UV and global radiation course of five days in January 2003 that is characteristic of the whole period. The UV and global radiation course was mostly similar; just in several cases it had marked differences, for example, on 3 January. On 4 January the UV and global radiation course varied insignificantly, but on 2 and 3 January their course differed by about $20 \%$. It was observed that UV radiation made up about one hundredth part of global radiation.

The annual course of ground-level ozone depends on the measurement site location, pollution level of the region, etc. Mostly the following seasonal course variations are observed: the ozone level increases in spring and decreases in summer, the total ozone level increases in spring - summer [6].

In 2002-2003 an average ground-level ozone concentration (Fig 7) increase was observed in April March, and the second one - in August. Increase in ozone concentration was found only in the spring of 2003. The least monthly average concentration in both years was in November. It should be noted that such late-autumn minimum values were observed at this sta-

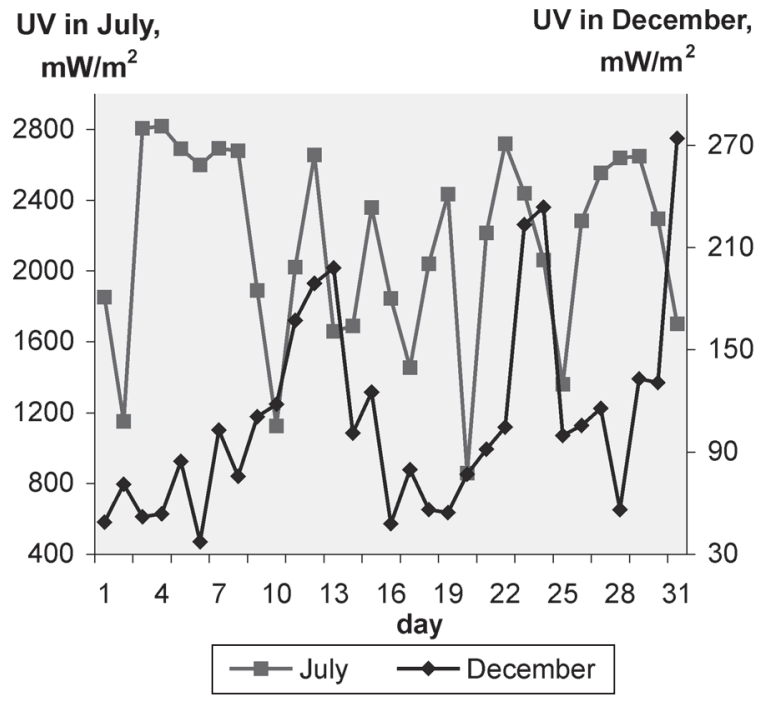

Fig 5. Average values of UV radiation in several months of 2002

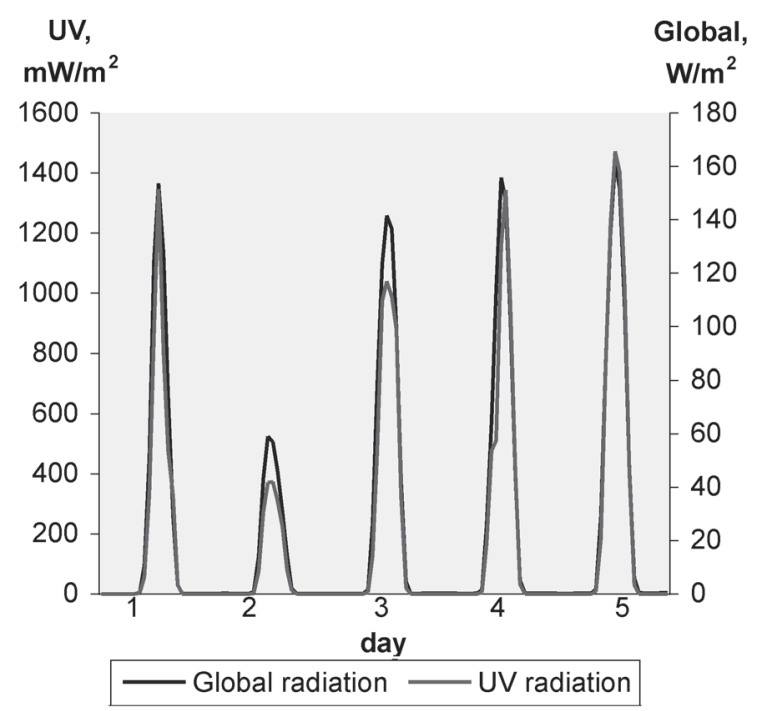

Fig 6. Course of global and UV radiation in January 2002

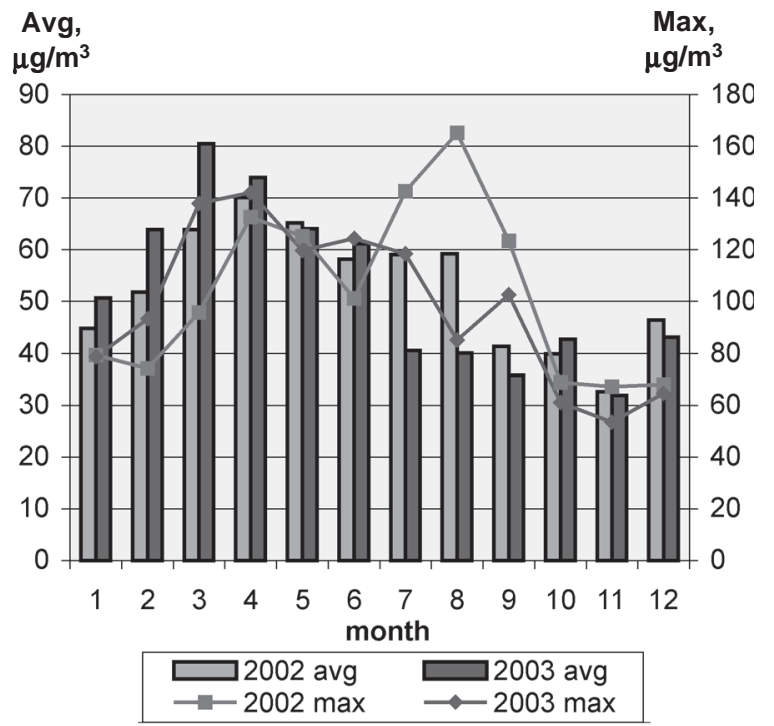

Fig 7. Monthly average and maximum values of ozone concentration in 2002-2003 


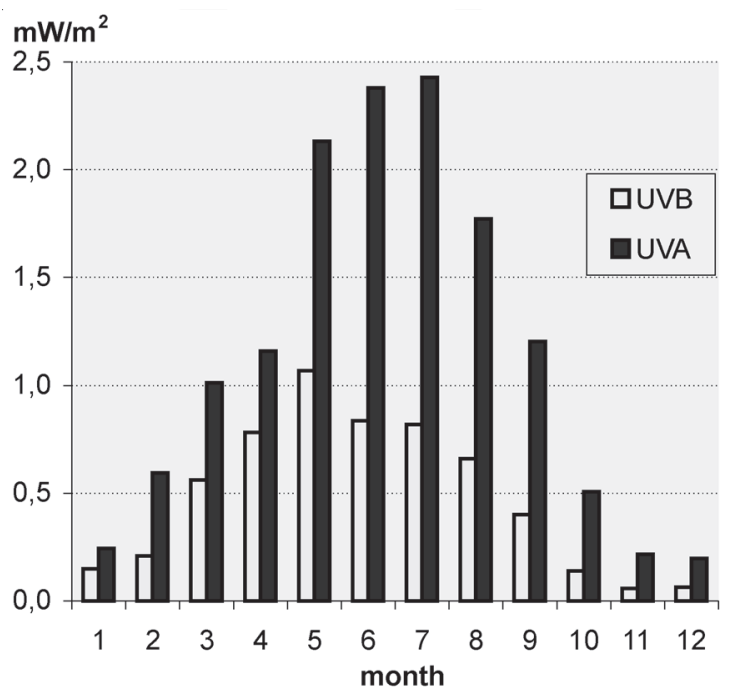

Fig 8. Average values of UVA and UVB radiation in 2002 (UVB radiation values multiplied by 10 )

tion practically every year. Maximum concentrations were registered in different months. As the data of Fig 7 show, the highest ground-level ozone concentration was in August $\left(165 \mu \mathrm{g} / \mathrm{m}^{3}\right)$ and in April $\left(142 \mu \mathrm{g} / \mathrm{m}^{3}\right)$ during 2002 and 2003.

The maximum of the monthly average intensity of UVA radiation was observed in July $\left(2,4 \mathrm{~W} / \mathrm{m}^{2}\right)$, and the minimum - in December $\left(0,1 \mathrm{~W} / \mathrm{m}^{2}\right)$ (Fig 8$)$.

The lowest value of UVB radiation intensity, like that of UVA radiation, was measured in December and reached only $0,007 \mathrm{~W} / \mathrm{m}^{2}$. UVB radiation was the most intensive in May $\left(0,09 \mathrm{~W} / \mathrm{m}^{2}\right)$.

UVB radiation plays an important role in tropospheric photochemistry, since it determines the rate of ozone photolysis $\mathrm{J}(\mathrm{O} 1 \mathrm{D})$ and subsequent formation of $\mathrm{OH}$ radicals. Consequently, changes of UVB radiation, e $g$ due to changes of the stratospheric ozone amount, could alter the concentration of reactive tropospheric gases, including ozone. Preliminary investigation of relationship between maximum daily ozone concentrations and UVB radiation maximum values were accomplished (Fig 9). The data in the summer (June-August) of 2003 were investigated. The results showed that in the case of higher UVB radiation values higher ozone concentra-

Table 2. Correlation coefficients between UVA, UVB radiation and ozone, and between UVA and UVB radiation

\begin{tabular}{|c|l|c|c|c|}
\hline \multirow{2}{*}{ Year } & & $\begin{array}{c}\text { UVA and } \\
\text { ozone }\end{array}$ & $\begin{array}{c}\text { UVB and } \\
\text { ozone }\end{array}$ & $\begin{array}{c}\text { UVA and } \\
\text { UVB }\end{array}$ \\
\hline \multirow{3}{*}{2002} & Whole year & 0,46 & 0,48 & 0,97 \\
\cline { 2 - 5 } & May-July & 0,47 & 0,51 & 0,97 \\
\cline { 2 - 5 } & $\begin{array}{l}\text { December- } \\
\text { February }\end{array}$ & 0,21 & 0,19 & 0,98 \\
\hline \multirow{2}{*}{2003} & Whole year & 0,32 & 0,29 & 0,99 \\
\cline { 2 - 5 } & May-July & 0,47 & 0,50 & 0,98 \\
\cline { 2 - 5 } & $\begin{array}{l}\text { December- } \\
\text { February }\end{array}$ & 0,30 & 0,29 & 0,99 \\
\hline
\end{tabular}

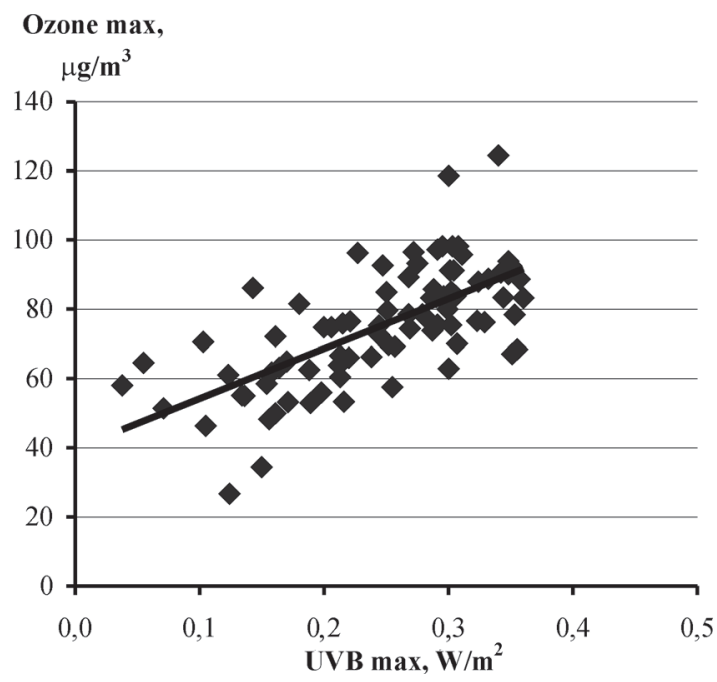

Fig 9. Scatter chart of ozone and UVB radiation data

tions were simultaneously observed. It should be noted that in estimating this dependence the presence of clouds or precipitation was not taken into account. It can be stated that relationship between UVB radiation and ozone concentration should be stronger including data only during sunny days.

The correlation describes the strength or degree of linear relationship [7] between two variables. Correlation coefficients between average daily ozone concentration and UVA radiation, average daily ozone concentration and UVB radiation, and between UVA and UVB radiation during separate periods in 2002-2003 are shown in Table 2. Larger correlation coefficients between ozone and UV radiation were established during summer months. It is evident that during summer months, when more sunny days are observed and weather temperature is rather high, conditions for photochemical ozone formation are favourable. Therefore, the correlation coefficient is larger than that calculated for the whole year. Correlation between these parameters during winter months is smaller about 2-2,5 times compared with that of the whole year and summer season.

The correlation coefficient between UVA and UVB radiation values is practically 1,0 (Table 2), and it means that UVA and UVB radiation data are strongly correlative.

The scatter chart (Fig 9) shows relationship between two variables. According to relationship between ozone and maximum UVB values, a regression equation can be written:

$C_{\mathrm{O} 3}\left[\mu \mathrm{g} / \mathrm{m}^{3}\right]=C^{0}{ }_{\mathrm{O} 3}\left[\mu \mathrm{g} / \mathrm{m}^{3}\right]+A[\mu \mathrm{g} / \mathrm{m} \times \mathrm{mW}] \times$

$I_{\mathrm{UVB}}\left[\mathrm{mW} / \mathrm{m}^{2}\right]$

where $C_{\mathrm{O} 3}$ is ozone concentration at $I_{\mathrm{UVB}}, C^{0}{ }_{\mathrm{O} 3}$ is ozone concentration at $I_{\mathrm{UVB}}=0, I_{\mathrm{UVB}}$ is UVB radiation and $A$ coefficient (slope of the regression line). 
In the summer of 2003 the value $C^{0}{ }_{\mathrm{O} 3}$ is $20 \mu \mathrm{g} / \mathrm{m}^{3}$, and the value $A$ is $220 \mu \mathrm{g} / \mathrm{m} \times \mathrm{mW}$.

\section{Conclusions}

1. Preliminary analysis of the data on UV radiation and ground-level ozone concentration from Rugšteliškès Monitoring Station was performed. It is confirmed that the course of UV and global radiation is similar; therefore, it is often possible to calculate the UV radiation intensity from global radiation data. The UV radiation value made up about one hundredth part of global radiation. It was determined that average values of UV radiation in January and July during 2002-2003 differed about 10 times.

2. The course of seasonal ozone concentration and UVB radiation can be different in unpolluted areas where Rugšteliškès Station is located. This difference points out that not only a photochemical process determines a high ozone concentration in summertime. However, it was determined that the highest ozone concentration was related to the highest UVB radiation values during the investigation period.

\section{References}

1. Palancar, G.; Toselli, M. Effects of meteorogy and tropospheric aerosols on UV-B radiation: a 4-year study. Atmospheric Environment, No 38, 2004, p 2749-2757.

2. Newman, P. Stratospheric Ozone. Electronic Textbook: http://www.ccpo.odu.edu/SEES/ozone/class/Chap_1/index.htm, 2004.

3. Maršalka, A.; Milutienè, E.; Augulienè, V. Evaluation of solar resources in Lithuania. Environmental and Chemical Physics, Vol 26, No 1, 2004, p 22-26.

4. Zerefos, C. S.; Kourtidis, K. A.; Melas, D.; Balis, D., Zanis, P.; Mantis, H. T.; Repapis, C.; Isaksen, I.; Sundet, J.; Herman, J.; Bhartia, P. K. and B. Calpini. Photochemical Activity and Solar Ultraviolet Radiation Modulation Factors (PAUR): An overview of the project. Journal of Geophysical Research, Vol 107, No D18, 2002, p 134-137.

5. Palancar, G.; Toselli, M. Effects of meteorogy on the annual and interannual cycle of UV-B and total radiation in Cordoba City, Argentina. Atmospheric Environment, No 38, 2004, p 1073-1082.

6. Girgždienè, R.; Girgždys, A. Variations of the seasonal ozone cycles in the Preila station over the 1988-2001 period. Environmental and Chemical Physics, Vol 25, No 1, 2003, p 11-15.

7. Čekanavičius, V.; Murauskas, G. Statistic and its uses. (Statistika ir jos taikymai). Vilnius, 2003. 98 p (in Lithuanian).

\section{ULTRAVIOLETINĖS SPINDULIUOTĖS IR PAŽEMIO OZONO POKYČIAI LIETUVOJE}

\section{R. Chadyšienė, R. Girgždienè, A. Girgždys}

S a n tra u a

Darbe nagrinėjami 2002-2003 m. Aukštaitijos ekologinio monitoringo stotyje gauti UV spinduliuotès ir pažemio ozono koncentracijų duomenys. Nustatyta, kad didžiausias UVA spinduliuotės intensyvumas yra liepos mėnesi - apie $2,4 \mathrm{~W} / \mathrm{m}^{2}$, o mažiausias - gruodi $-0,1 \mathrm{~W} / \mathrm{m}^{2}$. UVB spinduliuote intensyviausia gegužès mènesi $-0,09 \mathrm{~W} / \mathrm{m}^{2}$, o mažiausia jos verte, kaip ir UVA, užregistruota gruodi $-0,007 \mathrm{~W} / \mathrm{m}^{2}$. Pažemio ozono koncentracijos metiniai duomenys rodo du ryškius koncentracijos padidejimus - gegužès ir rugpjūčio mènesiais. Palyginus su bendraja spinduliuote, nustatyta, kad UV spinduliuote sudaro apie vieną šimtają jos dali. Vasaros mėnesiais, kai daugiau giedrų dienų, koreliacija yra didesnè nei per visus metus.

Raktažodžiai: ultravioletinè spinduliuote, spinduliuotès intensyvumas, ozono koncentracija, koreliacijos koeficientas.

\section{ИЗМЕНЕНИЯ КОНЦЕНТРАЦИИ УЛЬТРАФИОЛЕТОВОГО ИЗЛУЧЕНИЯ И ОКОЛОЗЕМНОГО ОЗОНА В ЛИТВЕ}

\section{Р. Хадишене, Р. Гиргждене, А. Гиргждис}

Р е $з$ ю м е

Анализируются зарегистрированные в 2002-2003 гг. данные об изменении ультрафиолетового (УФ) излучения и околоземного озона на экологической испытательной станции в Аукштайтии. Установлено, что наибольшая интенсивность УФА излучения наблюдается в июле - около $2,4 \mathrm{~W} / \mathrm{m}^{2}$, а наименьшая в декабре $-0,1 \mathrm{~W} / \mathrm{m}^{2}$. Наибольшая интенсивность УФБ излучения зарегистрирована в мае $-0,09 \mathrm{~W} / \mathrm{m}^{2}$, а наименьшая, как и для УФА, в декабре и составила $0,007 \mathrm{~W} / \mathrm{m}^{2}$. В течение рассматриваемого года наблюдалось два значительных увеличения концентраций околоземного озона - в мае и августе. Сравнением общего и УФ излучения установлено, что УФ излучение составляет около одной сотой части общего излучения. В летние месяцы, когда больше безоблачных дней, корреляция больше, чем в течение года.

Ключевые слова: ультрафиолетовое излучение, интенсивность излучения, озон, концентрация, коэффициент корреляции. 
Renata CHADYŠIENĖ. MSc, doctoral student, Dept of Physics, Vilnius Gediminas Technical University (VGTU), Sauletekio al. 11, LT-10223 Vilnius-40, Lithuania. E-mail: Renata.Chadysiene@fm.vtu.lt

Doctoral student (environmental engineering and landscape management), VGTU, 2004. Master of Science (ecology), VGTU, 2004. Publications: co-author of 1 research paper. Research interests: environmental protection, ultraviolet radiation, ozone monitoring.

Raselė GIRGŽDIENE். Dr, head of Laboratory of Ozone Research, Institute of Physics, Savanorių g. 231, LT-02300 Vilnius, Lithuania. E-mail: raseleg@ktl.mii.lt

Doctor of Science (environmental physics), Institute of Physics, 1986. First degree in Physics, Vilnius University (VU), 1970. Publications: author of over 120 research papers. Conferences: participant of 8 national and international conferences. Research interests: tropospheric ozone, ozone monitoring.

Aloyzas GIRGŽDYS. Dr, deputy director (since 1986) of Institute of Physics, Savanorių g. 231, LT-02300 Vilnius, Lithuania. E-mail: girgzdys@ktl.mii.lt

Doctor of Science (environmental physics), Moscow Institute of Atmospheric Physics, 1985. First degree in Physics, Vilnius University (VU), 1970. Publications: author of 1 monograph, over 120 research papers. Research interests: environmental physics, aerosol physics. 